\title{
Isus Krist - Početnik i Dovršitelj vjere
}

\author{
HrVoje KALEM* \\ • https://doi.org/10.31823/d.26.4.1 • \\ UDK: 27-184.3-312-05 Balthasar, H. U. • Izvorni znanstveni rad \\ Primljeno: 8. lipnja 2018. Prihvaćeno: 6. prosinca 2018.
}

${ }^{*}$ Dr. sc. Hrvoje Kalem,

Katolički bogoslovni fakultet u Đakovu

Sveučilišta J. J.

Strossmayera u Osijeku, P. Preradovića 17, p. p. 54, 31400 Đakovo, hrvojekalem@gmail.com

Sažetak: Pitanje vjere sržno je teološko i egzistencijalno pitanje. Vjernikova vjera ima svoj uzor u Isusovoj vjeri na koju se slabo ukazivalo u povijesti teologije. Obnovljeno promišljanje o fides Christi započinje se s Hansom Ursom von Balthasarom $i$ to u njegovu istoimenom djelu. Na tragu njegove misli u članku se promišlja o novozavjetnoj vjeri kao upotpunjenju starozavjetne. $U$ drugom koraku donosi se misao o Kristovoj vjeri do koje se dolazi fenomenološkim putem, promatrajući Isusov odnos prema Ocu kako ga opisuje Novi zavjet. Iz toga će postati razvidno da je Isusov odnos prema Ocu paradigma svakoga vjerničkoga odnosa prema Bogu, što je tema trećega dijela ovoga clanka. U zadnjem koraku artikulira se pitanje vjere u eshatonu pokazujući da je vjera potrebna i u gledanju Boga licem u lice jer se Otajstvo nikada ne može iscrpiti. Nakon rezimea članak kratko upućuje na vjeru kao put svetosti na koji nas poziva Božja svetost.

Ključne riječi: novozavjetna i starozavjetna vjera, fides Christi, gledanje Boga, arhetipsko iskustvo, kršćanska vjera, vjera u eshatonu.

\section{Uvod}

Govoriti o vjeri ne znači baviti se samo kršćanskom vjerom u Isusa Krista kao onoga koji nam otvara pristup vječnoj Trojstvenoj ljubavi. Takav stav jasno je vidljiv iz evanđeoskih izvještaja u kojima se vjera izražava kao povjerenje i vjernost u dolazak i ostvarenje kraljevstva Božjega. Ono je prisutno već sada, ali još ne. $\mathrm{Na}$ jedinstven način prisutno je u osobi Isusa Krista koji ga očituje liječeći bolesne, opra- 
štajući grijehe, susrećući marginalizirane i naviještajući radost siromasima. Drugi vid kršćanske vjere koji možemo iščitati iz novozavjetnih tekstova jest u vjeri koja nastaje iz susreta s Uskrslim. S vjerom u Isusovo uskrsnuće stoji ili pada naša vjera. To nedvojbeno potvrđuje sveti Pavao: $\gg$ A ako Krist nije uskrsnuo, uzaludna je vjera vaša, još ste u grijesima.« (1 Kor 15,17$)$ U Ivanovu evanđelju vjera označava odgovor cijeloga čovjeka Bogu. Njegovi tekstovi obiluju izričajem vjere koja se shvaća kao vjerovati u Krista i vjerovati Kristu. ${ }^{1}$

U ovome radu ne kanimo se baviti tim kratko naznačenim poimanjima vjere ni nekim drugim teološkim vidovima vjere, nego želimo na tragu kratkoga djela o Isusovoj vjeri švicarskoga teologa Hansa Ursa von Balthasara (1905. - 1988.), koje je objavio pod naslovom Fides Christi ${ }^{2}$, osvijetliti pitanje Isusove vjere u subjektivnom smislu, odnosno pozabaviti se pitanjem vjere u kristološkoj perspektivi. Drugim riječima, u ovome radu pitamo se je li Isus vjerovao, odnosno kako možemo opravdati biblijsku tvrdnju o Isusu kao Početniku i Dovršitelju vjere (Heb 12, 2). Ako je odgovor na pitanje o Isusovoj vjeri pozitivan, tada nam se - nakon pojašnjenja da je novozavjetna vjera upotpunjenje starozavjetne, a ne nikakva radikalna novost - nameće pitanje o vjeri onih koji slijede Isusa, njegov primjer i stil života. Stoga ćemo u ovome radu, slijedeći Balthasarovu misao, pokušati odgovoriti i na pitanje kakva je i u čemu se sastoji vjera kršćana u odnosu na Isusovu vjeru. Sljedeće pitanje koje proizlazi iz takva poimanja vjere jest stanje vjere u eshatološkoj perspektivi, odnosno prestaje li vjera nakon ovozemaljskoga života, odnosno dovršetka spasenja, ili ona zajedno s nadom i ljubavlju ostaje trajni čovjekov stav pred Misterijem i u visio facialis.

\section{Starozavjetna i novozavjetna vjera}

Novi zavjet, teologija prvih kršćanskih stoljeća, kao i ona skolastička, nisu se posebno bavili pitanjem Isusove vjere. Razlog te šutnje može se naći u možebitnom

\footnotetext{
${ }^{1}$ Usp. P. CODA, Teo-logia. La parola di Dio nelle parole dell'uomo, Roma, ${ }^{22009 .,} 93 \mathrm{~s}$.

${ }^{2}$ Usp. H. U. von BALTHASAR, Fides Christi, u: ISTI, Sponsa Verbi, Milano, 2015., 31-61. Balthasarova promišljanja o vjeri mogu se sintetizirati u tri faze. U prvoj fazi naš autor poima vjeru kao naš susret $\mathrm{s}$ objavom kao iskustvom ljepote u kojoj u Kristu kao Gestaltu opažamo Božju nazočnost. Takvom promišljanju posvećen je jedan dio prvoga volumena njegova djela Gloria. U drugoj fazi vjeru bismo mogli opisati kao dramu dviju sloboda: Božje i ljudske. Upravo je drama slobode u srcu vjere. Tim pitanjem Balthasar se pozabavio u trećem volumenu svoje Teodramatike. U trećoj fazi Balthasarovih promišljanja o vjeri vidimo ju kao pokret, odnosno kao nasljedovanje i participaciju na Kristovoj vjeri. Time se naš autor dijelom pozabavio u sedmom volumenu svoga djela Gloria. Usp. M. P. GALLAGHER, Mappe della Fede. Dieci grandi esploratori cristiani, Milano, 2011., 69-85.; A. BASTONI, La Fides Christi in Hans Urs von Balthasar, u: P. CODA, CH. HENNECKE (ur.), La fede: evento e promessa, Roma, 2000., 197.
} 
strahu od redukcionizma Isusova jedinstvena identiteta. ${ }^{3}$ Kada je i samo periferno doticala pitanje Isusove vjere, gotovo sva teologija, od Augustina preko Tome Akvinskoga, nijekala je da Krist posjeduje vjeru ili se tim pitanjem nije bavila. Unatoč tomu radikalnomu otklonu ipak nije mogla izbjeći neke suprotne argumente. Ti argumenti artikuliraju se u trima točkama. Prvo, vjera je krjepost uzvišenija od svih moralnih krjeposti, te je zbog toga morala pristajati i Isusu. Drugi argument koji se našao protivan tezi da Isus nije posjedovao vjeru ticao se činjenice da Isus ne bi mogao naučavati o krjepostima koje sam nije imao. Ako je on početnik i dovršitelj vjere, onda ju je morao posjedovati. Treći argument ticao se eshatološke perspektive vjere u kojoj se tvrdilo da blaženi moraju posjedovati vjeru jer će, prema Rim 1, 17, pravednik živjeti od vjere. ${ }^{4}$ Toma Akvinski u svojoj teološkoj Summi postavlja pitanje je li Krist imao vjeru te vrlo kratko odgovora negativno. ${ }^{5}$ Razlog odbacivanja takve tvrdnje, prema Akvincu, leži u tome što je objekt vjere božansko koje mi sada ne možemo vidjeti, a Krist je od prvoga trenutka svoga začeća u potpunosti vidio Boga u njegovoj biti i zbog toga ne može posjedovati vjeru. ${ }^{6}$ Ovdje jasno uočavamo kako je posve zaobiđeno poimanje vjere kao predanje Bogu i pouzdanje u njega, što se ponajbolje očituje u molitvenom stavu. Upravo je Isusova molitva Ocu, kao i ponovno teološko promišljanje o vjeri kao izručenju, predaji i pouzdanju, širom otvorila vrata mogućnosti govora o Isusovoj vjeri.?

Neposredan povod za ponovni govor o Isusovoj vjeri u teološkom diskursu bilo je promišljanje Martina Bubera o dvama tipovima vjere: starozavjetnoj i novozavjet-

\footnotetext{
${ }^{3}$ Usp. P. CODA, Teo-logia, 95.

${ }^{4}$ Usp. H. U. von BALTHASAR, Fides Christi, 48s.

${ }^{5}$ Usp. T. AKVINSKI, Summa theologica, III, q. 7, a. 3. Zanimljivo je kako Toma Akvinski negira Kristovu vjeru za vrijeme zemaljskoga života, ali mu na temelju svetopisamskih dokaza pripisuje poslušnost. Balthasar dobro uočava možebitni Tomin previd kad se pita koja se to forma i stupanj neznanja traže za takvu poslušnost Sina koji je postao čovjekom. Ako je Sin Božji nama u svemu jednak osim u grijehu, ne pripadaju li tu onda i temeljni stavovi zemaljskoga života: nada, poslušnost, strpljivost, vjernost itd. (Usp. H. U. von BALTHASAR, Fides Christi, 53.) Balthasar pravi distancu od toga Tomina iskaza, prema kojemu bi Isus na zemlji imao blaženo gledanje Boga (visio beatifica), te nudi mnogo šire tumačenje i poimanje vjere kao odgovarajući odnos čovjeka s Bogom tumačeći taj odnos na esencijalno-egzistencijalan način. Usp. M. HODŽIĆ, La genesi della fede. La formazione della coscienza credente tra essere riconosciuto ed essere riconoscente, Roma, 2009., 58.

${ }^{6}$ Usp. H. U. von BALTHASAR, Fides Christi, 49. Polazeći od svijesti koju je Isus imao o sebi i svome poslanju, koji su identični, treba podcrtati da je ta svijest o samome sebi stupnjevito sazrijevala te se očitovala u Isusovu susretu s osobama, događajima i ambijentom koji ga je okruživao. Upravo se time nadilazi skolastičko uvjerenje o negiranju vjere u Isusa. Usp. A. BASTONI, La Fides Christi in Hans Urs von Balthasar, 210.

${ }^{7}$ Usp. M. HODŽIĆ, La genesi della fede, 33-35. U bilješci 40 autor donosi teologe koji su pro i contra glede mogućnosti Isusove vjere.
} 
noj. Balthasar je, u svome već spomenutom djelu, donio kritički osvrt na Buberova promišljanja. Naime Buber opisuje starozavjetnu vjeru kao povjerenje i pouzdanje u Boga, s naglaskom na subjektivnu i osobnu dimenziju vjere koja uključuje sigurnost da je istinito i ispravno sve ono što Bog čini, obećava i govori o sebi. Novozavjetna vjera, prema Buberu, bila bi shvaćena kao spoznaja i prihvaćanje povijesnoga događaja da je Isus iz Nazareta Krist, Mesija i Spasitelj svijeta, a ta vjera bila je prenesena posredstvom svjedočenja te je ona bitno dogmatski artikulirana. Takvo Buberovo razgraničenje između novozavjetne i starozavjetne vjere neprihvatljivo je, ponajprije zato što vodi dokidanju razumijevanja novozavjetne vjere kao ispunjenja starozavjetne (usp. Mt 5, 17) te predstavlja novozavjetnu vjeru kao zamje-

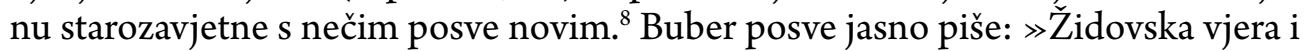
kršćanska vjera su, u njihovu odnosu, bitno različite, svaka po sličnosti s vlastitim ljudskim korijenima, i ostat će bitno različite sve dok ljudski rod ne bude okupljen iz 'progonstva' religija u Kraljevstvo Božje. «9

U analogiji između Staroga i Novoga saveza gdje je Novi ispunjenje Staroga možemo i novozavjetnu vjeru promatrati kao ispunjenje starozavjetne. Za starozavjetnoga čovjeka jednako je reći da vjeruje u Boga i da vjeruje u njegove zapovijedi, obećanja te osobito u izabranje, savez i njegovu riječ. To znači da starozavjetni vjernik vjeruje da se Bog na te različite načine približava svomu narodu i čini mu se nazočnim, daje mu se u svojoj vjernosti, izručuje mu se. Time Bog pokazuje svoju vjernosti. S te točke motrišta Božja vjernost i nepromjenjivost nisu Božji atributi koji bi mogli i ne postojati, nego izraz Božjega božanstva. To vrlo dobro apostrofira i sveti Pavao: $\gg$ Ako ne budemo vjerni, on vjeran ostaje. Ta ne može sebe zanijekati.« (2 Tim 2, 13). Stoga se pojam vjernosti/vjere može primijeniti i na Boga kao fidelitas Dei, odnosno kao Božja vjernost savezu i svomu narodu. Takva Božja vjernost, prema Balthasaru, motivira specifičan oblik ljudske vjere, $t j$. one vjernosti koja se oslanja na prepoznavanje Boga kao Boga i na čovjekovo cjelovito izručenje Njemu. Tim se Božja vjernost predstavlja kao uzor i prototip vjernosti. ${ }^{10} \mathrm{Iz}$ te perspektive postaje jasnija dugo vremena prijeporna rečenica iz Izaijine knjige: $\gg$ Ako se na me ne oslonite, održat' se nećete.« (Iz 7,9)

Ako se Bog mogao dati svome narodu kroz događaje i činove povijesno dohvatljive, pa čak i u trenutku njegova ropstva - sa svom bremenitošću toga pojma (Bog pohađa svoj narod u poganskoj i nepoznatoj zemlji i u njoj im upućuje svoju riječ) - tada je još razumljivije i posve prihvatljivije uvjerenje da se Bog u punini vremena

\footnotetext{
${ }^{8}$ Usp. H. U. von BALTHASAR, Fides Christi, 32. O Buberovoj distinkciji vidi više u: M. BUBER, Due tipi di fede. Fede ebraica e fede cristiana, Milano, 1999., osobito 57-206.

${ }^{9}$ M. BUBER, Due tipi di fede. Fede ebraica e fede cristiana, 206.

${ }^{10}$ Usp. H. U. von BALTHASAR, Fides Christi, 35., 37.
} 
(usp. Gal 4, 4) - i sada već u zemlji Izraelaca - daje u svojoj Riječi koja u određenom povijesnom trenutku postaje tijelom. Prihvaćanje toga novoga Božjega očitovanja vjernosti svome savezu, kroz utjelovljenu Riječ, nije ništa drugo doli različit modalitet iste vjere. ${ }^{11}$ Božje utjelovljenje kojim nastavlja pokazivati svoju vjernost, pa i nevjernomu, ali svomu narodu, spada u konstantnost i permanentnost Božje vjernosti i Božje brige za svoj narod. Time Buberova intencija o novozavjetnoj vjeri kao nečemu posve novomu što zamjenjuje starozavjetnu vjeru biva posve ogoljena i neodrživa.

Vjernost izabranju, Savezu, riječima proroka, Zakonima i Spisima modalitet je vjerovanja koji prethodi vjerovanju u utjelovljenu Riječ, kao definitivnu, konačnu ili posljednju Božju Riječ. ${ }^{12}$ Prividna promjena koja se, prema Balthasaru, događa, jest u činjenici da se u Novom zavjetu poruka o Božjoj utjelovljenoj Riječi predstavlja kao kerygma svjedoka koji prenose navještaj Isusova uskrsnuća te je taj navještaj upućen onima koji ne znaju za njegov sadržaj i onima koji u tom navještaju trebaju prihvatiti vjeru Crkve i vjeru u Boga. No, analizirajući starozavjetnu vjeru, postaje jasno kako prenošenje Božje riječi, a time i svjedočenje, nije ništa novo jer ono postoji u Arona, proroka i Mojsija koji prenose Božju riječ narodu. U tom prenošenju Bog zahtijeva poslušnost ne samo prema riječi nego i prema onima koji je posreduju. Jednako se tako događa i u Novom zavjetu. Druga i bitnija razlika koju Balthasar analizira, pozivajući se na Rudolfa Bultmanna, tiče se činjenice da pobožni Izraelac vjeruje u Boga zbog Božjega zahvata. Međutim ti zahvati nemaju potrebu da se $u$ njih vjeruje jer su očigledni u povijesti izraelskoga naroda, dočim u Novom zavjetu Božji intervent koji zahtijeva vjeru u najizvrsnijem smislu te koji po sebi nije očit jest ludost križa koja je Božja mudrost (usp. 1 Kor 1, 17-25), odnosno uvjerenje da je raspeti, uskrsnuli i proslavljeni Gospodin. To ne pripada području očiglednosti i nije jasno odmah na prvi pogled, nego to postaje tek po navještaju. Balthasar upućuje na to kako se upravo u pojavljivanjima Uskrsloga nastavlja govoriti o vjeri što je pokazatelj da vjera pred uskrsnućem i vjera onih koji nisu u mogućnosti tjelesno vidjeti Uskrsloga, nego vjeruju na temelju navještaja i svjedočanstava, nije držanje istinitim neke mogućnosti, nego se sastoji $\mathrm{u}$ daru ljubavi vlastite osobe koja u sebi sadrži privlačnu snagu. ${ }^{13}$ No, ako se pogleda dublje, u toj razlici između starozavjetnoga i novozavjetnoga vjerovanja naglasak nije toliko na navještaju i svjedočenju,

\footnotetext{
${ }^{11}$ Usp. isto, 32.

${ }^{12}$ U tome kontekstu iznimno je djelo H. VERWEJENA, Gottes letztes Wort. Grundriss der Fundamentaltheologie, Regensburg, 2000.

${ }^{13}$ Usp. H. U. von BALTHASAR, Gloria I, Milano, ${ }^{2}$ 2012. (= Gloria I), 184-186.
} 
nego na većoj napetosti unutar dijalektike Božje Riječi u kojoj se u isto vrijeme Bog objavljuje i, objavljujući se, ostaje skriven. ${ }^{14}$

Možemo reći da je ovdje na djelu dinamika Božjega samoočitovanja u kojoj Bog u ludosti križa objavljuje svoju Mudrost. Takav paradoks između ludosti i mudrosti može biti viđen kao formalni hermeneutski ključ kojim je moguće otkloniti čestu statičnost kršćanskoga vjerovanja, koje svoj vrhunac nerijetko očituje u neshvatljivom ponavljanju i recitiranju formula te vjeri shvaćenoj kao mrtva tradicija, a ne kao otvorenost Bogu iznutra. Upravo taj paradoks pomaže vjerniku da svoj život oblikuje slušajući Boga pa, ako je potrebno, i hrvajući se s njim, a ne samo recitirajući Bogu.

\section{Kristova vjera}

Imajući u vidu razumijevanje starozavjetne vjere koja u svim svojim konceptima, pa i u grčkim i latinskim prijevodima ${ }^{15}$, obuhvaća stav vjernosti, nade, iščekivanja, predanosti, povjerenja, stajanja i hodanja uz Gospodina te klanjanja Gospodinu što je $u$ sintezi vidljivo u svetkovini Tijelova kako je opisuje Joseph Ratzinger ${ }^{16}$, a na taj način možemo opisati i pravjeru izraelskoga naroda - tada je nemoguće da takav stav čovjeka pred Bogom bude nepoznanica čovjeku koji je pred Bogom savršen Isusu Kristu. ${ }^{17}$

Prije nego što se upustimo u promišljanje o Isusovoj vjeri, moramo pojasniti da ako vjeru shvatimo kao kerygmu i tvrdnje sadržane u njoj, a koje se iz nje mogu izvesti, ne možemo govoriti o Kristovoj vjeri jer je on bitni sadržaj te kerygme, punina $\mathrm{i}$ vrhunac objave. $U$ tom smislu on je iznad vjere, on ne vjeruje, vjera tada ne priliči njegovoj situaciji. Isus u tom smislu ne stoji na onoj strani gdje se vjeruje, nego na onoj kojoj se vjeruje. On čini vjeru mogućom. ${ }^{18}$ Kada zajedno s Balthasarom govorimo o Isusovoj vjeri, tada mislimo na vjerničku svijest koju je Isus imao o sebi i koju fenomenološkim putem možemo spoznati iz njegova odnosa s Ocem i svega onoga što je činio i govorio (gestis et verbis). To vrijedi za one riječi koje su formulirane tek u postpashalnoj zajednici, npr. proroštvo o vlastitoj muci i riječi kod posljednje

\footnotetext{
${ }^{14}$ Usp. H. U. von BALTHASAR, Fides Christi, 33. Kao što u Starome zavjetu čin vjere kojim se pokazuje vjera u Boga nije tražio da se u jednakoj mjeri vjeruje prorocima jer se takva vjera odnosi samo na Boga, jednako tako ni Crkva i njezini predstavnici ne zahtijevaju da se vjeruje u njih. Navještaj ili kerygma traži vjeru zbog njezina božanskoga sadržaja i poziva na božanski autoritet. Usp. isto, 34 .

${ }^{15}$ Usp. C. SPICQ, M-F. LACAN, »Vjera $\ll$ i »Vjernost « u: X. LÉON-DUFOUR (ur.), Rječnik biblijske teologije, Zagreb, ${ }^{4}$ 1993., 1420-1437.

${ }^{16}$ Usp. J. RATZINGER, Bog je s nama. Euharistija: središte života, Split, 2004., 115-123.

${ }^{17}$ Usp. H. U. von BALTHASAR, Fides Christi, 37.

${ }^{18}$ Usp. isto, 38.
} 
večere, ali koje u Isusu otkrivaju svijest o njegovu odnosu s Ocem te identitetu koji se podudara s njegovim poslanjem. ${ }^{19}$ Mislimo na vjeru kao temeljni čovjekov stav naspram Boga objavitelja, odnosno kao interpersonalnu relaciju, sukladno nauku Drugoga vatikanskoga sabora. ${ }^{20}$

Da bi pokazao neodrživost Buberova radikalnoga razdvajanja starozavjetne i novozavjetne vjere, Balthasar u kristološkom ključu pokazuje da se kršćanska vjera temelji upravo na fides Christi (na Kristovoj vjeri) kao prototipu i prauzoru te kako je upravo kršćanska vjera najviše i najvjernije ostvarenje vjere cijeloga Staroga zavjeta, a nikakva njezina zamjena ili nešto radikalno novo u smislu stava. Balthasar dolazi do takvoga zaključka fenomenološkim putem, odnosno promatrajući cijeli Isusov život onako kako je prikazan u Novom zavjetu, a osobito u Ivanovu evanđelju, da bi izišla na vidjelo subjektivna dimenzija Isusova događaja koja je utemeljujuća i početna. U takvom je fenomenološkom pristupu polazna točka Isusov odnos prema Ocu te iskustvo koje se iščitava iz Isusova života i djela: iz njegova proročko-eshatološkoga navještaja Kraljevstva, njegova odnosa prema Zakonu, bezuvjetnoga prihvaćanja Očeve volje i potpune slobodne poslušnosti Ocu. Iz takva Isusova odnosa prema Ocu izbija snaga Boga koji se daje u Isusu. On ne poziva na svoju snagu, nego na Boga kojega moli (usp. Mk 9, 29) te iz toga utemeljuje vjeru koja bi trebala biti i u njegovim učenicima. ${ }^{21}$ Upravo Isusova molitva, ${ }^{22}$ kao čin vjere i čin svijesti da je prepoznat/priznat i da prepoznaje/priznaje Očinstvo/božanstvo Boga/Oca, objavljuje njegov fides. Sinovska molitva koju Otac očekuje od svojih sinova nalazi se kao uzor upravo u čovještvu jedinorođenoga Sina. Isusova molitva izraz je prianjanja njegove ljudske volje Očevoj volji, potpuno izručenje toj volji što pokazuje istinsku vjerničku svijest. ${ }^{23}$

Ta radikalna vjernost Ocu koja ima svoj vrhunac u Isusovoj smrti predstavlja vrhunac vjere koju je Isus živio u odnosu s Ocem. Taj stav vjernosti prema Ocu i Oca prema Sinu potvrđen je u Isusovu uskrsnuću. Nije riječ samo o ispunjenju Isusova

\footnotetext{
${ }^{19}$ Usp. isto, 47.

${ }^{20}$ Usp. DRUGI VATIKANSKI KONCIL, Dogmatska konstitucija o božanskoj objavi »Dei Verbum $\ll$, u: ISTI, Dokumenti, Zagreb, ${ }^{5} 1998$., br. 5.

${ }^{21}$ Usp. H. U. von BALTHASAR, Fides Christi, 39s.

${ }^{22}$ Prema Ratzingeru Isus je Sin upravo zato što moli. Stavom molitve Sin pokazuje da je u dubini svoje egzistencije uvijek otvoren Bogu, time je uvijek u stavu slušanja, a svoju egzistenciju promatra kao razmjenu s Bogom te živi iz te razmjene koja može postati agonija i borba, ali koja kao takva u konačnici ima snažnije značenje u prihvaćanju ne svoje, nego Očeve volje. Time Sin ne zacrtava sam svoju egzistenciju, nego je prima iz najdubljega dijaloga s Ocem iz kojega razumije Pismo bolje od svih ljudi jer dolazi od samoga Boga. Usp. J. RATZINGER, Teološki nauk o principima. Elementi fundamentalne teologije, Rijeka, 2010., 34-35.

${ }^{23}$ Usp. M. HODŽIĆ, La genesi della fede, 35., bilj. 43.
} 
života kao utjelovljenoga Sina i potvrdi da Isus nije živio promašen život na zemlji te bio neki slučajni raspeti čovjek na Golgoti, kakvih je u to vrijeme bilo nemalo, nego je Isusovo uskrsnuće, kao čin kojim ga Bog potvrđuje, prostor koji otvara mogućnost takvoga ispunjenja svakom čovjeku, kao participacija na fides Christi. ${ }^{24}$ Isusova vjera tako se postavlja pred vjernika kao najvjerniji i najuzorniji odgovor Bogu. Isus posjeduje stav vjernosti prema Bogu u punini i zato je u stanju usaditi taj stav onima koji se pouzdaju u njega. I on to čini ponajprije svjedočenjem Boga u povijesti. ${ }^{25}$ Drugim riječima, on omogućuje vjeru ako je živi kao prauzor i pralik te prima od Boga spasenjsku moć da utisne u nas svoj življeni primjer. ${ }^{26}$

S obzirom na egzemplarni odnos prema Ocu Isusova ponuda kao posrednika Božje snage u njegovu darivanju i raspoloživosti za sve tumači se kao čin ljubavi, koja svoj vrhunac ima u smrti na križu. Ćinjenica da je Riječ Božja postala tijelom, odnosno da se Isus ponudio ljudima kao posrednik Božje snage u darivanju sama sebe, posljednji je izraz vjere Staroga zavjeta, izraz ljubavi i vjernosti prema Bogu i njegovoj spasenjskoj riječi. ${ }^{27} \mathrm{Na}$ taj način, svojim stavom on nije samo model vjere nego je i učinio mogućom vjeru Novoga zavjeta i svaku vjeru Staroga saveza čiji je on temelj $\mathrm{i}$ ispunjenje. Sve to ukazuje na to da je Isus početnik i dovršitelj naše vjere jer je podnio protivljenje grješnika i na sebe uzeo križ (usp. Heb 12, 2-3). Isus je prauzor vjere i zbog toga što je prvi među ljudima koji vjeruje u Boga kršćana. Time postaje razvidno kako fides Christi predstavlja živo raskrižje saveza između Boga i izabranoga naroda: »Zbog činjenice da je Riječ Božja postala čovjekom, utjelovljuje se u Njemu, u ljudskom obliku, fides Dei, savez Božje vjernosti s ljudskim rodom. Ovaj čovjek, koji je Sin Božji, puni izraz njegove biti i njegova plana ljubavi je 'Božja utjelovljena vjernost' u kojoj su sva Božja obećanja pronašla svoj da. ${ }^{28}$

Oslanjajući se na Dionizija Areopagitu koji gleda u Isusu exstasis božanskoga erosa izvan sebe u kojemu se Bog dariva svijetu, Balthasar vidi Isusovu vjeru kao prauzor svih vjera čovječanstva, te Isus tako postaje utjelovljeni savez čovječanstva s Bogom. Time Isus postaje temeljna, nezamjenjiva i vrhovna stvarnost odnosa između Boga

\footnotetext{
${ }^{24}$ Usp. P. CODA, Teo-logia, 95-98; H. U. von BALTHASAR, Gloria I, 323.

${ }^{25}$ Više o tome u H. U. von BALTHASAR, Gloria I, 157-175. Najeminentnije Božje svjedočanstvo u povijesti jest ono $\mathrm{u}$ formi Krista nazočnoga u svijetu. Odlučujući trenutak sastoji se u činjenici da ta forma predstavlja samu sebe kao objavu Božje unutarnje dubine i to snagom same svoje biti po savršenoj recipročnosti između svjedočenja Sina za Oca i Oca za Sina. Na taj način Krist može reći: »Tko u mene vjeruje, ne vjeruje u mene, nego u onoga koji me posla; i tko vidi mene, vidi onoga koji me posla.« (Iv 12, 44-45) Usp. isto.

${ }^{26}$ Usp. H. U. von BALTHASAR, Fides Christi, 38.

${ }^{27}$ Usp. isto, 41.

${ }^{28}$ Isto, 60.
} 
i svijeta. Utjelovljenjem je Isus uzeo na sebe ne samo moralnu nego i ontološku univerzalnu ljudsku vrijednost jer on od vječnosti nadvisuje sva individualna ograničenja. Taj savez između Boga i čovjeka posredovan je u Starom zavjetu po Mojsiju, no Krist sada zamjenjuje Mojsija na savršen i posve ispunjen način jer s njim ulazi na scenu sam Bog, čime Mojsijevo posredništvo postaje suvišno (usp. Gal 3, $19-21) .^{29}$

\section{Kršćanska vjera kao nasljedovanje fides Christi}

Kristova vjera nije ornament i poziv na statičnost i uljuljanost kršćanske vjere, nego je ona prije svega putokaz i prauzor onima koji žele nasljedovati Krista i staviti se na njegov put. Stoga je važno uočiti i pojasniti kako se prešlo s Kristove vjere na vjeru u Krista. U tom kontekstu Balthasar najprije odbacuje tumačenje pojmova vjera Isusa Krista i vjera u Isusa Krista, kao objektivni genitiv u kojemu bi Isus Krist bio objekt vjere. Jednako tako odbacuje i interpretaciju tih pojmova u smislu subjektivnoga genitiva, kao da je riječ o činu vjere samoga Krista, te se priklanja Deissmannovu tumačenju mističnoga genitiva i daljnjim razvojima toga tumačenja.

Alfred Dessimann poziva se na formule paralelne formuli Kristova vjera, npr. $\gg$ snaga Kristova « (2 Kor 12, 9), »bogatstvo Kristovo « (Ef 3, 8), »blagoslov Kristov« $(\operatorname{Rim} 15,29)$. Iz tumačenja mističnoga genitiva proizlazi da je vjera Isusa Krista vjera uronjena u stvarnost samoga Krista, vjera koja sudjeluje i čini mogućom puninu istine, ljubavi, muke i uskrsnuća Kristova i svih drugih vidova njegove stvarnosti. To je Abrahamova vjera u svetim vremenima početka, tj. bezuvjetno povjerenje $u$ živoga Boga. Abrahamova vjera usmjerena je prema Kristovoj vjeri koja je jednom zauvijek otvorila pristup Ocu. ${ }^{30}$ Tako se Kristova vjera pokazuje u njegovim nasljedovateljima.

Sadržaj i značenje mističnoga genitiva dalje razvija Ernst Lohmeyer pokazujući da riječ vjera ocrtava objektivnu stvarnost prema kojoj se usmjerava i na kojoj se temelji vjerničko ja. Prema Lohmeyerovu tumačenju, Pavao označava izraz Kristova vjera metafizičkim principom, a ljudski čin vjerovanja kao vjerovati $u$ Krista ili vjerovati snagom Krista. Govoriti o Kristovoj vjeri ne znači govoriti samo o vjeri koju Krist posjeduje ni o onoj koju on daje, dakle u smislu subjektivnoga ili objektivnoga genitiva, nego o vjeri koja je On sam. ${ }^{31}$ Vjera je tako Božje očitovanje koje budi, nuka i zahtijeva naš stav po uzoru na Kristov stav. Ovdje Balthasar podcrtava egzistencijalnu dimen-

\footnotetext{
${ }^{29}$ Usp. isto, 60-61. Prema biblijskim tvrdnjama Mojsiju se u Starom zavjetu pripisivalo najviše iskustvo Boga. To da je samo Jedinorođenac vidio Boga (usp. Iv 1, 18), prema Balthasaru, upereno je upravo protiv Mojsija. Usp. H. U. von BALTHASAR, Gloria I, 296s.

${ }^{30}$ Usp. H. U. von BALTHASAR, »Fides Christi $\ll$, 42-43.

${ }^{31}$ Usp. isto, 44.
} 
ziju vjere ističući kako vjera determinira ljudsku egzistenciju polazeći od trenutka u kojem s jedne strane sam Krist svojom kenozom, odnosno poslušnošću i trpljenjem, povijesno otvara pristup Ocu i s druge strane ako se sam Otac okreće svijetu u poslušnosti Sina i u obličju sluge. ${ }^{32}$ Kršćanska vjera tako je determinirana bilo stavom Sina naspram Oca bilo stavom Oca prema Sinu, što je jamstvo za svijet u mjeri u kojoj Sinovljev stav postaje metafizički princip koji obilježava svaki stav prema Bogu. ${ }^{33}$

U Isus Kristu susreću se Bog i čovjek. Tako Isus ima iskustvo onoga što je Bog i u isto vrijeme onoga što je čovjek. Takvo arhetipsko iskustvo dopušta Isusu da odredi svoj odnos prema Bogu, što se može nazvati njegovom vjerom, i da odredi vjeru svojih učenika. Dakle Isus determinira što je kršćanska vjera. Iz njegova odnosa $\mathrm{s}$ Ocem mi vidimo i učimo što je kršćanska vjera. ${ }^{34} \gg$ Iskustvo Boga koje je Isus živio bilo je apsolutno jedinstveno (Iv 1,18), nesvodivo na bilo koju biblijsku osobu, jer je shvatljivo samo u odnosu na dvostruko kretanja dolaska od Oca i odlaska Ocu. $\ll^{35}$

Govoreći o vjeri kao stavu, bilo kod Krista bilo kod onih koji ga nasljeduju, jasno je da vjera dodiruje sve dimenzije ljudske egzistencije i pojavljuje se kao egzistencijalna stvarnost, onkraj svake teorije. Tako je pravi model i uzor vjere čin Kristove egzistencije, čime se formula fides ex auditu ne odbacuje, nego se integrira u čin njegove egzistencije. Ili možda bolje: ona je implicitna nasljedovanju čina Kristove egzistencije. Upravo je svojim činom egzistencije Isus mogao postati početnik i dovršitelj vjere. ${ }^{36}$ I Pavlovo i Ivanovo iskustvo pokazuje da je vjera preobrazba cijeloga čovjeka u prostor odgovora na božanski sadržaj. Kod prvoga se to iskustvo sastoji u biti iščupan iz jednoga eona u drugi, npr. u događaju kod Damaska (usp. Dj 3, 9s.), a kod drugoga u dođite $i$ vidite (usp. Iv 1, 39). ${ }^{37}$

Ono što Isusa razlikuje od njegovih učenika jest to da je on pretrpio borbu vjere za njih. Tu Isusovu vjeru Bog prihvaća uskrisivši ga od mrtvih te ju daje zajednici kao dar vjere koji se prenosi. Blizina i udaljenost kršćanina od Krista ovako su karakte-

\footnotetext{
${ }^{32}$ Formi ljudske egzistencije pripada predavanje vlastite egzistencije u nasljedovanje jedne egzistencije i njezinoga nauka koji mu se očituje kao shvatljiv; posve je u skladu i razumljivo je čovjeku da svoju egzistenciju predaje Bogu. Usp. H. U. von BALTHASAR, Gloria I, 170.

${ }^{33}$ Usp. H. U. von BALTHASAR, Fides Christi, 45.

${ }^{34}$ Usp. H. U. von BALTHASAR, Gloria I, 280s.

${ }^{35}$ A. BASTONI, La Fides Christi in Hans Urs von Balthasar, 208.

${ }^{36}$ Važno je zapaziti da jedanaesto poglavlje Poslanice Hebrejima donosi popis osoba Staroga zavjeta koje su se istaknule svojom vjerom: Abraham, Henok, Noa, Jakov, Izak itd. Početak dvanaestoga poglavlja iste poslanice pojavljuje se kao vrhunac u kojem je Isus predstavljen kao početnik i dovršitelj te vjere. Već bi samo takvo tumačenje bilo dovoljno da se ospori Buberova teza o novozavjetnoj vjeri kao nečemu posve novom u odnosu na starozavjetnu.

${ }^{37}$ Usp. H. U. von BALTHASAR, Gloria I, 206-223.
} 
rizirane: doći do vjere znači staviti se zajedno s Kristom pred Gospodina, znači vjerovati kao Isus da ga Bog uslišava. No naša vjera razlikuje se od Isusove jer je nama rečeno u ime Isusa, polazeći od Uskrsa, da ga je Bog čuo (uslišao). Kršćanska vjera ne može se shvatiti drukčije nego kao nasljedovanje i ulaženje u Isusov najintimniji stav, kao stajanje s povijesnim Isusom pred Bogom i vjerovanje da Bog uslišava. Ono što opravdava vjeru upravo je činjenica da Bog uskrsnućem odgovara na Isusovu odvažnost. Običan čovjek ne bi nikada mogao bez pretpostavke (navještaja) ostvariti cjelovitost vjere koju se zahtijevalo od Isusa bez jedne više nego ljudske pomoći. ${ }^{38}$ Isus nije u svojoj vjeri mogao imati to iskustvo niti mu je to moglo biti naviješteno kao što Crkva u vjeri naviješta događaj uskrsnuća s kojim stoji ili pada naša vjera. Zbog toga je Isusov stav vjernosti, posvemašnjega predanja i poslušnosti Ocu stav koji trebamo nasljedovati, ali koji nikada ne ćemo moći do kraja iskusiti i dostići jer mi svoju vjeru živimo u vjeri koja nam je prenesena - u vjeri u Isusovo uskrsnuće, koje je paradigma našim nadanjima. Zbog toga je naša vjera participacija na Kristovoj vjeri kao prauzoru i praliku svakoga odnosa prema Bogu. Isus je prvouskrsnuli i njemu nije mogla biti priopćena ta tajna vjere od koje bi mogao živjeti i na temelju koje bi se mogao nadati. Time njegov radikalni stav potpune $\mathrm{i}$ bezuvjetne predanosti i izručenosti Ocu još više dobiva na snazi.

Razlika između Isusove i naše vjere ogleda se još i u činjenici da Isus u svome potpunom izručenju Ocu nije imao potrebe ni za kakvim posrednikom ni djelom posrednika jer je on sam Posrednik za svakoga čovjeka. Naša vjera i Isusova vjera na kojoj mi participiramo razlikuju se i u činjenici da između Isusove osobe i njegova poslanja postoji potpuna podudarnost, dok u našem vjerničkom iskustvu nema identičnosti između poslanja i osobe, nego ono dolazi kao posljedica prianjanja uz Boga u vjeri. ${ }^{39}$

\section{Eshatološka perspektiva vjere}

Vjera je u Starome zavjetu čovjekov savršen stav tijekom njegova zemaljskoga života. O eshatološkoj perspektivi vjere u Starome zavjetu govori se malo i nejasno. Balthasar pokazuje da je i novozavjetna eshatologija, jednako kao i vjera, upotpunjenje starozavjetne, a nikako njezina zamjena ili nešto posve novo. ${ }^{40}$ Balthasar odavde počinje naširoko analizu vjere koja postoji u eshatološkoj perspektivi. On to zaključuje polazeći od uskrsnuća tijela u kojemu su prisutni znakovi čavala. Time naš autor uzima u obzir preobraženje i umetanje u vječnost svih vidova u kojima se u vremenu bitno izražava odnos s Bogom. To je u skladu sa slavom (doksa) koju

\footnotetext{
${ }^{38}$ Usp. H. U. von BALTHASAR, Fides Christi, 47. Vrijedna su i promišljanja apostolskih otaca koja opisuju vjeru kao strpljivu ustrajnost u nasljedovanju trpećega Krista (Polikarp); Za Ignacija vjera znači biti uzeti s Isusom na križ, no svaka vjera odgovor je na Božju vjernost. Usp. isto, 48.

${ }^{39}$ Usp. A. BASTONI, La Fides Christi in Hans Urs von Balthasar, 216.

${ }^{40}$ Usp. H. U. von BALTHASAR, Fides Christi, 56.
} 
evanđelist Ivan vidi već unutar Kristove smrtne čovječnosti, dapače ta slava odsijeva više nego ikada baš dok se izvršava njegova muka i smrt. ${ }^{41}$

Polazeći od tamnih trenutaka vjere, Balthasar uviđa kako vjeri unutarnje pripada moment tame, mraka, jer samo tama može jamčiti slobodu i mjerodavnost čina vjere. Balthasar se u tome oslanja na jedinstveno promišljanje koje donosi Matteo d'Acquasparta. Naspram Bonaventurinu i Tominu mišljenju, prema kojemu je u gledanju licem u lice vjera nemoguća i za Krista i za blažene, Matteo d'Acquasparta drži da ni u nebu nema shvatljivoga/jasnoga gledanja Boga jer božanska beskonačnost ostaje uvijek veća od mogućnosti gledanja stvorenja, čak i u svjetlu slave. ${ }^{42}$ D’Acquasparta drži da blaženici vide Boga, ali ga ne mogu razumjeti do te mjere da ga iscrpe te to uvijek imaju u vidu. Božji misterij uvijek ostaje misterijem. Iz toga slijedi da se može reći kako blaženi vjeruju nešto jer nikada ne mogu znati sve; svatko je od njih duhovni subjekt, ali ima i svoje unutarnje područje puno misterija u koje nitko drugi ne može zabiti pogled i koje svatko mora objaviti drugomu posredstvom dokazivanja. Tako se događa da ako jedan anđeo drugomu objavi svoj misterij, jedan drugomu vjeruje jer zna da mu ovaj drugi ne može lagati. ${ }^{43}$

Takvo i druga skolastička promišljanja ukazuju na to da je skolastika nastojala sačuvati pozitivni moment vjere i nade u gledanju i u posjedovanju vječnoga života. Dakle čovjek nije lišen vjere ni u eshatonu, ali jednako tako u tom stanju ne prestaju ni nada ni ljubav. $U$ vezi s tim Balthasar se utječe jednoj staroj interpretaciji 1 Kor 13, 13 koju su poznavali Tertulijan i Irenej, a kojoj je naklonjen i Origen, u kojoj se kaže kako će dar jezika, proroštva i spoznaje uminuti, dok ostaje ljubav koja sve vjeruje i svemu se nada, te se zaključuje da ostaju to troje: vjera nada i ljubav. Tako se vjera, nada ${ }^{44} \mathrm{i}$ ljubav pokazuju kao karizme koje ostaju. Ljubav ima primat, prema himnu u 1 Kor 13, 13, ali ona je vječna zajedno s vjerom i nadom jer s njima tvori trajnu strukturu života vjernika kao Božjega sina. Mi ljubimo kao što je Bog ljubio nas i na način na koji nas je ljubio. Upravo je ljubav koja podrazumijeva u sebi vjeru i nadu ono što Bog dariva i zahtijeva ${ }^{45} \mathrm{i}$ ono što nikada ne prestaje. ${ }^{46}$

\footnotetext{
${ }^{41}$ Usp. isto, 50.

${ }^{42}$ Time postaje razvidno da se gledanje Boga licem u lice ne može interpretirati kao comprehensio u smislu znanosti i filozofije. Aksiom si comprehendis non est Deus vrijedi na nebu kao i na zemlji samo s promjenom iz spes u res. Usp. H. U. von BALTHASAR, Gloria I, 432.

${ }^{43}$ Usp. H. U. von BALTHASAR, Fides Christi, 51-53.

${ }^{44}$ Pavao poznaje i zemaljski modalitet nade u Rim 8, 24-25 koja nije dio onih triju koje sačinjavaju naš vječni život. Usp. H. U. von BALTHASAR, Fides Christi, 55.

${ }^{45}$ Usp. isto, 53-55.

${ }^{46}$ Te tri teologalne krjeposti prožimaju se i imaju svoj život poput trojstvenoga života. One su, prema Lacanu, očitovanje jedincatoga temeljenoga stava Staroga zavjeta u kojem se ta tri vida nalaze zajedno još uvijek nerazlikovani i kao takvi neodvojivi. Usp. isto, 55.
} 
Osobito je u iskustvu mistika vidljiv dinamički koncept eshatona u kojem $\gg$ stvorenje koje gleda Boga ne prestaje u Njemu otkrivati i od Njega očekivati uvijek nešto novo, darujući mu se u uvijek novoj vjernoj privrženosti $\ll{ }^{47}$ Vjera je tako, prema tumačenju Jakoba Taubesa na kojega se Balthasar referira, izraz mesijasnko-eshatološke egzistencije, koja nije samo stav iščekivanja koji bi mogao biti nadiđen dolaskom Mesije nego mesijanski stav u sebi definiran, tj. participacija na Mesijinoj formi egzistencije, koja je u Novom zavjetu raspeti Logos. I 2 Kor 5, 1-7 govori o preobrazbi zemaljskoga u nebeski šator. Taj nebeski šator koji nam je potreban da ne upoznamo da smo goli (usp. Post 3,7 ) može biti samo participacija na čovještvu proslavljenoga Krista, što je preliminarni uvjet da možemo kontemplirati slavu jer je sam Krist Božja slava. Taj nebeski šator potreban nam je da bismo mogli kontemplirati i podnijeti slavu neizrecivoga Boga. ${ }^{48}$

Oslanjajući se na Karla Rahnera, Balthasar podcrtava kako se i Isusova ljudska duša upravo u blaženom gledanju (beata visio) nalazi pred neshvatljivošću Boga, ona ne shvaća Boga, ne prodire do njegove dubine. Za to se, prema Balthasaru, može posve mirno reći da je katolička dogma. Takvo stajanje pred neshvatljivošću Boga, koje se još više tiče ljudi koji gledaju Boga, nije nikakvo mučenje, nego predanost u ljubavi i povjerenje u Beskonačno. ${ }^{49} \mathrm{Na}$ koncu, u takvome odnosu riječ je o prepoznavanju da smo prepoznati/priznati pred Bogom. U teofanijama Staroga zavjeta vidjeti Boga u njegovu hramu značilo je prije svega biti viđen od Boga. Živa vjera zadovoljena je samo stajanjem pred licem Boga koji vidi, bez brige vidimo li ga ili ne. ${ }^{50}$

\section{Zaključak}

Isusova vjera iščitava se iz njegova jedinstvena stava prema Ocu. Time je Hans Urs von Balthasar u svome kratkom djelu Fides Christi pokazao novozavjetnu vjeru kao upotpunjenje starozavjetne, a nikako kao nešto posve radikalno novo. Isus stoji kao početnik i dovršitelj stava vjernosti prema Jahvi koju su imali Abraham, Henok, Noa, Jakov, Josip i druge velike starozavjetne ličnosti. Svojim činom egzistencije koju je moguće evidentirati fenomenološkim putem Isus pokazuje radikalnu vjer-

\footnotetext{
${ }^{47}$ Isto, 56.

${ }^{48}$ Usp. isto, 56-58.

${ }^{49}$ Usp. isto, 58. Apofatička ili negativna teologija koja je s Dionizijem Areopagitom i Maksimom Ispovjedaocem ušla u kršćansku teologiju pokazuje da je vjera excessus ili izlazak onkraj svakoga znanja. Riječ je o spoznaji Boga u tami razuma, tj. o spoznaji onkraj svakoga vovs-a, u mističnom oblaku neznanja. Takva spoznaja uključuje patnju, ali ne u stoičkom smislu, nego patnju koja ne postoji bez ljubavi. Usp. J. RATZINGER, Luce, u: G. RIVA (ur.), Dizionario teologico II, Brescia, 1967. 232-243.

${ }^{50}$ Usp. H. U. von BALTHASAR, Gloria I, 303.
} 
nost prema Ocu, a svojim dvostrukim kretanjem, dolaskom od Oca i odlaskom k Ocu, očituje apsolutnu jedinstvenost vjere na kojoj vjernici participiraju. Iz Isusova stava i odnosa prema Ocu vjera se pokazuje kao stav čovjeka koji u sebi pronalazi posvemašnju ovisnost o Bogu nastojeći se posve suobličiti njegovoj volji kroz sinovsku molitvu i potpuno prianjanje uz njega. ${ }^{51}$

To iskustvo koje Isus ima iz odnosa s Ocem neka je vrsta nadvjere koja je jednaka gledanju Oca. Iskustvo Boga koje imaju učenici jest nasljedovanje koje se neodvojivo sastoji u vjeri u Isusa Krista i s Kristom u Boga. ${ }^{52}$ Arhetipsko iskustvo vjernika samo je participacija na Kristovu iskustvu Boga. Krist čini cijelu Crkvu dionicom toga iskustva ujedinjujući se sa svakim članom Crkve. Apsolutno jedinstveni sinovski odnos s Ocem, koji je Isus iskusio u svome zemaljskom životu, za nas je arhetipska figura. Ne može se prihvatiti generički koncept vjere te ga onda primijeniti na Isusa, nego je figura Isusove vjerničke svijesti paradigma vjerničke svijest nas vjernika. ${ }^{53}$

Pokazujući subjektivnu dimenziju Isusove vjere koju mi vjernici nasljedujemo, Balthasar je naspram Buberu uspio pokazati kršćansku vjeru kao ispunjenje starozavjetne. To se vidi i kad se govori o eshatološkoj perspektivi vjere. Naša vjera u konačnici je nasljedovanje Božje vjernosti koja se utjelovila u Isusu Kristu. Božju vjernost jasno uočavamo promatrajući povijest spasenja, ali na jedinstven način ta Božja vjernost nam se pokazuje i u eshatonu, u potpunom i savršenom zajedništvu s njim, pa je onda naša obveza vjernošću odgovoriti na tu Božju vjernost i u eshatonu. Time smo, zajedno s Balthasarom, pokazali postojanje vjere i u blaženom gledanju, što ukazuje na dinamički koncept samoga eshatona.

Nasljedujući Krista koji utjelovljuje fidelitas Dei, mi nasljedujemo Božju vjernost, a ako nasljedujemo vjernost, onda nasljedujemo i njegovu svetost na koju nas poziva: »Sveti budite! Jer sam svet ja, Jahve, Bog vaš! (Lev 19, 2) Tako je i svetost svetaca i svih kršćana u cjelini, odnosno Crkve Kristove kao svetoga puka (usp. $1 \mathrm{Pt}$ 2,9) sudjelovanje na Božjoj svetosti, a vjera kao sudjelovanje na fides Christi pokazuje se kao put prema svetosti.

\footnotetext{
${ }^{51}$ Usp. A. BASTONI, La Fides Christi in Hans Urs von Balthasar, 204.

${ }^{52}$ Usp. H. U. von BALTHASAR, Gloria I, 282s.

${ }^{53}$ Usp. M. HODŽIĆ, La genesi della fede, 35-36.
} 


\title{
JESUS CHRIST - THE PIONEER AND PERFECTER OF THE FAITH
}

\author{
Hrvoje KALEM*
}

Summary: The question of faith is a core theological and existential question. The faith of believers has its ideal in the faith of Jesus, which was poorly pointed to in the history of theology. The renewed reflection on the fides Christi begins with Hans Urs von Balthasar in his work of the same name. Following his decree, the article reflects on the New Testament faith as a complement to the Old Testament faith. In the second step, we reflect on the faith of Christ to which we arrive in a phenomenological way, by observing Jesus' relationship with the Father as described in the New Testament. From this it will become apparent that Jesus' relationship with the Father is a paradigm of every believer's relationship with God, which is the theme of the third part of the article. In the last step, the question of faith is discussed in the eschaton, showing that faith is also needed in looking God face to face, because the Mystery can never be exhausted. After a résumé, the article briefly points to faith as a way of holiness to which we are called by God's holiness.

Keywords: New Testament and Old Testament faith, fides Christi, looking at God, archetypal experience, Christian faith, faith in eschaton.

\footnotetext{
* Hrvoje Kalem, Ph. D., Catholic Faculty of Theology in Đakovo, J. J. Strossmayer University of Osijek, P. Preradovića 17, P.O. box 54, 31400 Đakovo, Croatia, hrvojekalem@gmail.com
} 